\title{
Bladder Cancer pTa TNM Finding v6 and
} v7

National Cancer Institute

\section{Source}

National Cancer Institute. Bladder Cancer pTa TNM Finding v6 and v7. NCI Thesaurus. Code C61207.

Bladder cancer with a finding of noninvasive papillary carcinoma. (from AJCC 6th and 7th Eds.) 